\title{
Psychometric Properties of The Goldberg Anxiety and Depression Scale (GADS) In Ecuadorian Population
}

\author{
Propiedades psicométricas de la Escala de Ansiedad y Depresión de Goldberg (GADS) en población \\ ecuatoriana
}

Geovanny Reivan-Ortiz ${ }^{1, *}$, Gisela Pineda-Garcia², and Bello Darío León Parias ${ }^{3}$

\begin{abstract}
The objective of the present study was to analyze the psychometric properties of validity and reliability of the Goldberg Anxiety and Depression Scale (GADS) in Ecuadorian university students, since a cultural validation of the instrument has not been found in Ecuador. The study population consisted of a non-probabilistic sample of 600 participants $(59.6 \%$ women and $40.4 \%$ men, $M=21$ years, SD = 2.82). The factorial structure was examined with the method of extraction by Parallel Analysis of unweighted least squares (ULS) and of prominent rotation. In both, internal consistency was evaluated by Cronbach's alpha coefficients and composite reliability. Like the original version, both subscales have a factorial structure of one dimension and are considered good in terms of reliability, which concludes that the scale meets the criteria of validity and reliability in Ecuador.

\section{Resumen}

El objetivo del presente estudio fue analizar las propiedades psicométricas de validez y fiabilidad de la Escala de Ansiedad y Depresión de Goldberg (EAD-G) en estudiantes universitarios ecuatorianos, ya que no se ha encontrado una validación cultural en Ecuador del instrumento. La población estudiada estuvo conformada por una muestra no probabilística de 600 participantes (59.6\% de mujeres y $40.4 \%$ de hombres; $M=21$ años, DT $=2.82$ ). La estructura factorial se examinó con el método de extracción por Análisis Paralelo de mínimos cuadrados no ponderados (ULS) y de rotación promin. En tanto a la consistencia interna se evaluó por coeficientes de alfa de Cronbach y fiabilidad compuesta. Al igual que la versión original ambas subescalas presentan una estructura factorial de una dimensión y es considerada buena en términos de fiabilidad, lo cual se concluye que la escala cumple con los criterios de validez y confiabilidad para la cultura ecuatoriana.
\end{abstract}

Keywords:

Anxiety, Depression, Psychometric Analysis, Reliability, Validity.

Palabras Claves:

Ansiedad, depresión, análisis psicométrico, confiabilidad, validez.

1. Universidad de Palermo, Argentina. Universidad Católica de Cuenca, Ecuador.

2. Universidad Autónoma de Baja California, México.

3. Universidad de Antioquia, Colombia.

* Corresponding author greiva@palermo.edu; greivano@ucacue.edu.ec; geovannyreiban@gmail.com

Manuscript received 13-09-2018; revised 07-11-2018; accepted 23-11-2018.

\section{Introduction}

Anxiety and depression disorders constitute the most common mental alterations of the general population. Data provided by the World Health Organization (2003) reveal ascendant values. At least 264 million people suffer anxiety disorders, equivalent to a $15 \%$ increase in the last decade, and approximately 322 million people suffer from depression, $18 \%$ more than 10 years ago. Anxiety and depression are significant disorders not only because they cause the deterioration of personal and family relationships, but also due to the socioeconomic implications related to healthcare costs and diminished work productivity and quality of life (Ayuso \& Álvarez, 2000).

Regarding clinical and symptom history, syndrome diagnosis of anxiety and depression disorders is nowadays primarily done by applying criteria in the 
Diagnostic and Statistical Manual of Mental Disorders (DSM-V, American Psychiatric Association, 2013), or in the ICD (CIE-10, World Health Organization, 1992), and secondarily, by use of clinical assessment instruments. In spite of their usefulness as an element of support to clinical diagnosis these instruments are used mainly as measuring scales of the severity of symptomatology associated with the disorder, thus signalling the presence of anxious or depressive pathology and at the same time determining the severity, proving very useful both in clinical practice and research (Salvador, Romero \& González, 2000). For this reason, it is essential that clinical scales are appropriate to the cultural environment where they are applied and that they have adequate psychometric properties of validity, reliability and sensitivity (Heyland, et al., 1998).

Goldberg Anxiety and Depression Scale (GADS) is a simple diagnostic tool, developed specifically to find out the probability that a state of anxiety or depression will occur. It was created by its author in 1988 as a short interview that could be used by healthcare personnel as a filtering instrument.

The dimensionality of the instrument was developed through analysis of latent features, in which item construction was deployed from data obtained from 427 patients who went to 15 general medical practitioners in Manchester. The data was then analyzed using the Psychiatric Assessment Schedule (Bond, Brooks, Carstairs \& Giles, 1980), General Health Questionnaire (Goldberg \& Hillier, 1979) and evaluated with the diagnosis criteria for generalized anxiety and major depression described in the Diagnostic and Statistical Manual of Mental Disorders DSM-IV, third revision (American Psychiatric Association, 1987, 2002).

With the purpose of examining the correlation between the symptoms of psychiatric disorders most commonly found in primary care clinics, two dimensions were identified: symptoms of anxiety and symptoms of depression which obtained a high direct correlation according to their defining characteristics.

Item formulation was done in two groups: detection items were four symptoms corresponding to the lowest thresholds, while probing items were the five symptoms with the highest thresholds. It was determined that the anxiety scale had $82 \%$ sensitivity and a positive 0.56 value; the depression scale had $85 \%$ sensitivity and a predictive value of positive 0.85 . General specificity was $91 \%$ and general sensitivity 86\% (Goldberg, Bridges, Duncan-Jones, \& Grayson, 1988).

GADS has been widely recommended as a tool for both healthcare and epidemiology, and/or a guide for primary care clinical interviews, which can produce bidimensional information about the severity of anxiety and/or depression (López, Gabarrón, \& Ruiz, 2011). Regarding cultural adaptations, the scale has been validated in numerous countries, among them the
Spanish version by Montón, Pérez Echeverría, Campos, García Campayo and Lobo (1993) for the Spanish population, which authors indicate has $83.1 \%$ sensitivity, $81.8 \%$ specificity and $95.3 \%$ positive predictive value. Also, in a survey of predictive validity in Cuba, it had an adequate predictive value in identifying patients with the disorders (Martín Carbonell, Pérez Díaz, \& Riquelme Marín, 2016). Nonetheless, GADS dimensionality has been assessed with the same validation method of the original scale through the analysis of latent features whose results support the bi-dimensional structure of the original scale (Koloski, Smith, Pachana \& Dobson, 2008; Mackinnon et al., 1994). In regard to reliability it showed a $0.81 \%$ internal consistency by the Cronbach's alpha coefficient for the full scale, 0.70 for the depression scale and 0.74 for the anxiety scale (Mackinnon et al., 1994).

In the Iranian version, the results of factorial analysis revealed that the scale explains $44.63 \%$ of the total variance (Aminpoor, Afshinfar, Mostafaei \& Ostovar, 2012); in the Australian adaptation its use was considered to be a valid tool for identifying cases of depression and anxiety (Kiely \& Butterworth, 2015). The Italian version used the method of main component analysis for its adaptation (Magnavita, 2007).

In addition, a survey conducted in the UK showed that GADS has good reliability as a measure of stability (Kinderman et al., 2015).

As far as the convergent validity of the scale, studies demonstrate a good correlation with the instruments of the following: the Spanish version of the scale of anxiety and pre-surgery information of Amsterdam APAIS (Vergara-Romero et al., 2017); the PRIME-MD (Primary Care Evaluation of Mental Disorders); and the MINI (Mini International Neuropsychiatic Interview) and the Goldberg Health Questionnaire Goldberg (GHQ28) (Bernardos, Larios \& Jimenez, 1999), showing statistically significant values higher than 0.70 .

The Goldberg Anxiety and Depression Scale is an instrument widely used in healthcare practice and in clinical research (Varo, Fernández, Cobos, Gutiérrez, \& Aragón, 2006).

A review of the availability of GADS in Ecuador showed that it was being used regularly in various occupational health centers in the country (ArellanoYépez \& Riofrío Andaluz, 2010; Espín Hernández, 2017; Granda Villavicencio, Aldude \& Vicente, 2017), without going through a process of cultural adaptation or formal validation.

Given that no previous psychometric studies of this instrument have been done in Ecuador, that there are surveys with different methods of analysis in versions that have been adapted into other languages, and that it methodologically speaking it is recommended to progress from exploratory to confirmatory stages in the factorial validation of the measuring scales 
(Lloret-Segura, Ferreres-Traver, Hernández-Baeza \& Tomás-Marco, 2014), we set as our goal to carry out an exploratory study of the factorial validity of GADS without a priori assuming any factorial model. Additionally, we sought to validate the reliability of this instrument in Ecuador by studying a sample of Ecuadorian university students, in order to provide a version that can be used in healthcare and clinical research in our environment.

\section{Method}

\section{Design}

A descriptive and correlational instrumental study was conducted.

\section{Participants}

The study population consisted in an accidental, nonprobabilistic sample (Hernández Sampieri, Fernández Collao, \& Baptista Lucio, 2015) of 609 psychology students from the Catholic University of Cuenca. A total of 600 valid answers were obtained (98.5\%), from $59.6 \%$ women and $40.4 \%$ men, with an average age of 21 years old $(\mathrm{DY}=2.82)$. As for the selection criteria, university psychology students of psychology that had signed an informed consent sheet were selected, whereas students under the effect of drugs (except tobacco) were excluded.

\section{Instruments}

Goldberg Anxiety and Depression Scale -GADS(Goldberg et al., 1988). This instrument is composed of two subscales of 9 binary (yes / no) items. The first subscale for anxiety, "Have you had difficulty relaxing?" (questions1 to 9); and the second subscale for depression, "Have you felt low energy?" (questions 10 to 18) were used. The initial questions of each subscale 1-4 and 10-13 respectively are conditioning questions. At least two affirmative answers are required for questions 1-4 to discontinue the subscale. For the second subscale, one positive answer is needed from questions $10-13$ to continue answering the subscale. The whole scale presents $91 \%$ specificity and $86 \%$ sensibility. The cut-off point for the anxiety subscale is 4 or more points and 2 or more points for the depression subscale. Higher point values indicate a more severe problem with 9 as the highest possible value for each subscale). Although the questions are very clear with binary responses, the authors consider that sometimes a low level of intensity is difficult to detect, and a professional judgment is needed to evaluate the clinical significance of the answers.

Sociodemographic questionnaire. A short survey to recollect personal data, such as age, gender and level of completed studies was used.

\section{Procedure}

GADS has been adapted to Spanish using a translationback translation methodology (Beaton, Bombardier, Guillemin \& Ferraz, 2000; Bullinger et al., 1998), as well as the by the Bulletin of the International Test Commission (Hambleton \& Bollwark, 1991; Hambleton \& Kanjee, 1995). Using this methodology, it was possible to substantiate semantic and structural equivalence between original items and the Spanish translation.

The scale was analyzed by three 3 Ecuadorian professional expert judges specializing in psychological quantification variables who determined the linguistic comprehension and the applicability of the scale in the Ecuadorian context. In this study the scale was compared to the Spanish version (Montón et al., 1993) showing evidence for semantic equality. Later, the scale was applied to a pilot sample $(\mathrm{N}=25)$ where linguistic comprehension was assured.

The Ethics Research Committee of the Catholic University of Cuenca approved the study and informed consent was obtained in accordance with the APA's Ethical Principles of Psychologists and Code of Conduct (American Psychiatric Association, 2002) for students who voluntarily participated in the study and signed the written document. The data collection process was conducted during the teachers' work time, emphasizing the anonymous character of the information obtained (Behnke, 2006).

\section{Data analysis}

The exploratory factorial analysis was carried out using the software program Factor version 10.0.02 (Ferrando \& Lorenzo Seva, 2017). In order to get the number of dimensions of the dispersion matrix of tetrachoric correlation (Muthén \& Hofacker, 1988), the extraction procedure for the two subscales was obtained by a parallel analysis (PA) (Timmerman \& Lorenzo-Seva, 2011) which is frequently recommended to evaluate the dimensionality of a set of variables. AP is known to be have been used in different variants that may produce different indications of dimensionality, hence it is considered the most appropriate method for evaluating the number of common factors underlying the ordered variables (Timmerman \& Lorenzo-Seva, 2011). Moreover, the procedure used to obtain the random correlation matrix was by raw data permutation (Buja \& Eyuboglu, 1992). Before performing KMO and Bartlett's Test of sphericity the extraction method was done by unweighted least squares (ULS). Promin was used to maximize factor simplicity (Lorenzo-Seva, 1999).

Each scale reliability analysis was carried out by calculating Cronbach's Alpha coefficient (Nunnally, 1975, Nunnally \& Bernstein, 1994). The reliability coefficient, or complex reliability (pc) reflects the degree to which observed variables are consistent to 
their measure of the latent construct as specified by the model. Equation 1 shows that the indicators are presented as $\lambda \mathrm{i}=$ standardized charge of indicator $\mathrm{i} ; \mathrm{i}=$ measurement error of indicator $i$; and y var $\varepsilon i=1-\lambda^{2} i$. Complex reliability (pc) is similar to Cronbach's Alpha as a measure of internal consistency. Nevertheless, the difference is that complex reliability uses item charges as they are supposed in the causal model. Fornell and Larcker (1981) argue that complex reliability is superior to Cronbach's Alpha, because it has a more general order and it is not influenced by the number of existing items on the scale. The interpretation of both indices is similar on each.

$$
\rho_{c}=\frac{\left(\sum \lambda_{i}\right)^{2}}{\left(\sum \lambda_{i}\right)^{2}+\sum_{i} \operatorname{var}\left(\varepsilon_{i}\right)}
$$

Equation 1. Composite Reliability (pc). Source: Werts, Linn, \& Jöreskog (1974)

Correlation item-factor was calculated by the extracted variance (Average Variance Extracted, AVE) of Fornell and Larcker (1981), which means that if the different items intended to measure a construct measure it accurately, the adjustment of these items is assumed to be significant and will be highly correlated. Evaluation of this process is done by means of the average variance extracted (AVE), which provides the amount of variance that a construct obtains from its indicators in relation to the amount of variance due to measurement error. The formula is established in Equation 2, as $\lambda \mathrm{i}=$ standardized charge of the indicatori; $\varepsilon i=$ measurement error of the indicator $i$, and $\mathrm{y}$ var $\varepsilon \mathrm{i}=1-\lambda^{2} \mathrm{i}$.

Authors recommend that extracted variance should be superior to 0.50 , establishing that more than $50 \%$ of the construct extracted variance is due to its indicators (Fornell \& Larcker, 1981). Nevertheless, it is argued that this is an extremely strict value (Malhotra \& Dash, 2011) and must be interpreted with flexibility.

$$
A V E=\frac{\sum \lambda_{i}^{2}}{\sum \lambda_{i}^{2}+\sum_{i} \operatorname{var}\left(\varepsilon_{i}\right)}
$$

Equation 2. Average Variance Extracted (AVE). Source: Fornell \& Larcker (1981)

\section{Results}

\section{Factorial structure}

Initially, it was confirmed by the pertinent statistical tests that the data could be subjected to factorial analysis.
The Kaiser-Meyer-Olkin (KMO) test obtained a 0.80 index for the anxiety scale and 0.86 for the depression scale. The result of the Bartlett's sphericity test was $\chi^{2}=947.8$ for the anxiety scale and $\chi^{2}=1248.0$ for the depression scale: $\mathrm{df}=36$ and $\mathrm{p}<0.01$ in both scales. Consequently, the relevant analyses were performed. Factor extraction by Parallel analysis for the anxiety subscale (Table 1), and for the depression scale (Table 2) suggest one dimension.

\section{Table 1}

Parallel Analysis (PA) of the Goldberg anxiety subscale based on the factor analysis of minimum range (Timmerman \& Lorenzo-Seva, 2011) in the Ecuadorian population.

\begin{tabular}{llll}
\hline Variable & $\begin{array}{l}\text { Real data } \\
\% \text { of variance }\end{array}$ & $\begin{array}{l}\text { Random Mean } \\
\% \text { of variance }\end{array}$ & $\begin{array}{l}\text { Random 95th } \\
\text { percentile } \\
\% \text { of variance }\end{array}$ \\
\hline 1 & $66.0 *$ & 37.0 & 51.3 \\
2 & 15.4 & 27.6 & 36.7 \\
3 & 8.2 & 17.1 & 27.2 \\
4 & 7.1 & 10.2 & 18.6 \\
5 & 2.9 & 6.0 & 9.4 \\
\hline
\end{tabular}

*Dimension recommended amount: 1

\section{Table 2}

Parallel Analysis (PA) of Goldberg depression subscale based on the factor analysis of minimum range (Timmerman \& Lorenzo-Seva, 2011) in Ecuadorian population

\begin{tabular}{llll}
\hline Variable & $\begin{array}{l}\text { Real data } \\
\% \text { of variance }\end{array}$ & $\begin{array}{l}\text { Random Mean } \\
\% \text { of variance }\end{array}$ & $\begin{array}{l}\text { Random 95th } \\
\text { percentile } \\
\% \text { of variance }\end{array}$ \\
\hline 1 & $68.1^{*}$ & 35.6 & 49.3 \\
2 & 14.1 & 27.5 & 35.8 \\
3 & 7.3 & 17.7 & 26.8 \\
4 & 5.8 & 10.8 & 19.3 \\
5 & 3.8 & 6.2 & 9.4 \\
\hline
\end{tabular}

* Dimension recommended amount: 1.

Variance explained by the eigenvalues; an accumulated percentage of 0.47 is observed for the anxiety subscale (Table 3), and a percentage of 0.54 for the depression subscale (Table 4). 
Table 3

Variance explained from the eigenvalues for the Goldberg anxiety subscale in Ecuadorian population

\begin{tabular}{llll}
\hline Variable & Eigenvalue & Mean Variance & $\begin{array}{l}\text { Accumulated } \\
\text { mean } \\
\text { Variance }\end{array}$ \\
\hline 1 & 4.24803 & 0.47200 & 0.47200 \\
2 & 1.06736 & 0.11860 & \\
3 & 0.91038 & 0.10115 & \\
4 & 0.73664 & 0.08185 & \\
5 & 0.65961 & 0.07329 & \\
6 & 0.50312 & 0.05590 & \\
7 & 0.42297 & 0.04700 & \\
8 & 0.27030 & 0.03003 & \\
9 & 0.18157 & 0.02017 & \\
\hline
\end{tabular}

Table 4

Explained variance based on eigenvalues for Goldberg depression subscale Goldberg in Ecuadorian population

\begin{tabular}{llll}
\hline Variable & Eigenvalue & Mean Variance & $\begin{array}{l}\text { Accumulated mean } \\
\text { Variance }\end{array}$ \\
\hline 1 & 4.87803 & 0.54200 & 0.54200 \\
2 & 1.05723 & 0.11747 & \\
3 & 0.74937 & 0.08326 & \\
4 & 0.60034 & 0.06670 & \\
5 & 0.58762 & 0.06529 & \\
6 & 0.38143 & 0.04238 & \\
7 & 0.29256 & 0.03251 & \\
8 & 0.25918 & 0.02880 & \\
9 & 0.19424 & 0.02158 & \\
\hline
\end{tabular}

\section{Internal consistency}

The instrument's reliability was first determined by the Cronbach's Alpha Coefficient for the anxiety subscale obtaining a 0.75 value, which is considered acceptable. The depression subscale obtained a value of .80, which is considered good (Nunnally \& Bernstein, 1994; Carmines \& Zeller, 1979). The complex reliability coefficient was also obtained (pc) for the anxiety subscale obtaining a 0.73 value. As for the depression subscale, a value of 0.78 was obtained, both considered acceptable.

\section{Correlation item-factor by the average variance extracted (AVE)}

Results showed a value of 0.28 for the anxiety subscale and a higher value for the depression subscale of 0.35 .

\section{Discussion}

The present research on instrumental adaptation had the objective of exploring the factorial structure and reliability of Goldberg's Scale on Anxiety and Depression (Goldberg et al., 1988), in a sample composed of university students from Ecuador. This scale assesses the severity of symptomatological anxiety and depression. The analysis of psychometric properties showed that the instrument possesses the same bidimensional structure of the original scale, as well as the distribution of the items in both subscales. As for internal consistency, the obtained indexes are shown to be acceptable and good. However, when the items-factor correlations times mean variance was analysed the values are slightly reduced, possibly due to the items being influenced by some external component. Nevertheless, as was mentioned before, this value must not be interpreted strictly, but flexibly (Malhotra \& Dash, 2011).

As for the research limitations (Price \& Murnan, 2004), since the sample is composed of university students, it is not possible to estimate the diagnostic validity of the sieving instrument with a reference diagnosis in terms of sensibility and specificity. Furthermore, the research was of a transversal cut, and the collection of data was of a psychometric scale, which does not allow us to obtain information about the instrument based on other reliability concepts such as the stability measure and/or alternative or parallel forms; the same applies to criterion validity as well as convergence, discrimination and/or predictive capacity (Hernández Sampieri et al., 2015). On the other hand, in the current methodology, even when the Factorial confirmatory analysis procedures are highly developed the same method is still used for confirmation (Pérez Gil, Chacón Moscoso, \& Moreno Rodríguez, 2000). Nonetheless, future studies utilizing factorial analysis should investigate and be compared with the factorial structure in the present research. Finally, the results indicate that GADS is a valid scale for Ecuadorian culture, allowing an updated version to be used in clinical, welfare and research practice, and applied to their environment.

Note: This research was part of an objective of a doctoral thesis of the University of Palermo, made by the main author. 


\section{References}

American Psychiatric Association. (1987). Diagnostic and statistical manual of mental disorders; revised. [Manual Diagnóstico y estadístico de trastornos mentales] (DSM-III-R). Washington DG: Author.

American Psychiatric Association. APA. (2002) Manual Diagnóstico e Estatístico de Transtornos Mentais. DSM-IV-TR (4ed. rev.). Porto Alegre: Artmed.

American Psychiatric Association. (2013). Diagnostic and statistical manual of mental disorders (DSM$5 \AA)$. Washington, DC: Author.

Aminpoor, H., Afshinfar, J., Mostafaei, A., \& Ostovar, S. (2012). Validation of Goldberg's Depression Scale in academic and non-academic peoples. Ann Biol Res, 3(9), 4564-4573.

Arellano Yépez, M. F., \& Riofrío Andaluz, C. F. (2010). Prevalencia de trastornos depresivos $y$ de ansiedad en el personal administrativo de la Pontificia Universidad Católica del Ecuador (Bachelors thesis). Pontificia Universidad Católica del Ecuador, Ecuador Recovered from: http://repositorio.puce.edu.ec/ handle/22000/5045

Ayuso, J. L., \& Álvarez, E. (2000). Depresión. Psiquiatría en Atención Primaria, 5, 6-11.

Beaton, D. E., Bombardier, C., Guillemin, F., \& Ferraz, M. B. (2000). Guidelines for the process of cross-cultural adaptation of self-report measures. Spine, 25(24), 3186-3191. https:// doi.org/10.1097/00007632-200012150-00014

Behnke, S. (2006). APA's Ethical Principles of Psychologists and Code of Conduct: An ethics code for all psychologists. Monitor on Psychology, 37(8), 66. doi:10.1037/ e532252006-041

Bernardos, R. M., Larios, A. B., \& Jimenez, M. O. (1999). ¿Podemos detectar trastornos mentales en atención primaria?. Utilidad y concordancia de dos instrumentos diagnósticos. Atención primaria: Publicación oficial de la Sociedad Española de Familia y Comunitaria, 23(5), 285-288.

Bond, J., Brooks, P., Carstairs, V., \& Giles, L. (1980). The reliability of a survey psychiatric assessment schedule for the elderly. The British Journal of Psychiatry, 137(2), 148-162. doi:10.1192/ bjp.137.2.148

Buja, A., \& Eyuboglu, N. (1992). Remarks on parallel analysis. Multivariate behavioral research, 27(4), 509-540. doi:10.1207/s15327906mbr2704_2
Bullinger, M., Alonso, J., Apolone, G., Leplège, A., Sullivan, M., Wood-Dauphinee, S., ... \& Fukuhara, S. (1998). Translating health status questionnaires and evaluating their quality: the IQOLA project approach. Journal of clinical epidemiology, 51(11), 913-923. https://doi. org/10.1016/S0895-4356(98)00082-1

Carmines, E. G., \& Zeller, R. A. (1979). Reliability and validity assessment (17th. Ed.). Sage publications.

Espín Hernández, K. A. (2017). Pacientes con diagnóstico de VIH positivo y su capacidad de resiliencia ante los niveles de ansiedad y depresión provocados por la enfermedad en el hospital San Vicente de Paúl en el periodo 2016-2017 (Bachelor's thesis). Universidad Técnica del Norte, Ecuador. Recovered from: http://repositorio.utn.edu.ec/ handle/123456789/6804

Ferrando, P. J., \& Lorenzo-Seva, U. (2017). Program FACTOR at 10: Origins, development and future directions. Psicothema, 29(2), 236-240. doi:10.7334/psicothema2016.304

Fornell, C., \& Larcker, D. F. (1981). Structural Equation Models with Unobservable Variables and Measurement Error: Algebra and Statistics. Journal of Marketing Research, 18(3), 382-388. doi:10.1177/002224378101800313

Goldberg, D. P., \& Hillier, V. F. (1979). A scaled version of the General Health Questionnaire. Psychological medicine, 9(1), 139-145. doi:10.1017/ S0033291700021644

Goldberg, D., Bridges, K., Duncan-Jones, P., \& Grayson, D. (1988). Detecting anxiety and depression in general medical settings. Bmj, 297(6653), 897899. doi:10.1136/bmj.297.6653.897

Granda Villavicencio, P. V., Aldude, H., \& Vicente, M. (2017). Relación entre niveles de ansiedad y dependencia física a la nicotina, así como su correlación con percepción de salud general y uso de cigarrillo electrónico en estudiantes de la Pontificia Universidad Católica del Ecuador (Bachelors thesis, PUCE). Pontificia Universidad Católica del Ecuador, Ecuador. Recovered from: http:// repositorio.puce.edu.ec/handle/22000/13970

Hambleton, R. K., \& Bollwark, J. (1991). Adapting Tests for Use in Different Cultures: Technical Issues and Methods. Recovered from: https:// eric.ed.gov/?id=ED337481

Hambleton, R. K., \& Kanjee, A. (1995). Increasing the validity of cross-cultural assessments: Use of improved methods for test adaptations. European Journal of Psychological Assessment, 11(3), 147-157. https://doi. org/10.1027/1015-5759.11.3.147 
Hernández Sampieri, R., Fernández Collado, C., \& Baptista Lucio, P. (2015). Metodología de la investigación. ( $6^{\text {th }}$ edition). México: McGraw-Hill.

Heyland, D. K., Guyatt, G., Cook, D. J., Meade, M., Juniper, E., Cronin, L., \& Gafni, A. (1998). Frequency and methodologic rigor of qualityof-life assessments in the critical care literature. Critical care medicine, 26(3), 591-598. doi:10.1097/00003246-19980300000037

Kiely, K. M., \& Butterworth, P. (2015). Validation of four measures of mental health against depression and generalized anxiety in a community based sample. Psychiatry research, 225(3), 291-298. doi:10.1016/j.psychres.2014.12.023

Kinderman, P., Tai, S., Pontin, E., Schwannauer, M., Jarman, I., \& Lisboa, P. (2015). Causal and mediating factors for anxiety, depression and well-being. British Journal of Psychiatry, 206(6), 456-460. doi:10.1192/bjp.bp.114.147553

Koloski, N. A., Smith, N., Pachana, N. A., \& Dobson, A. (2008). Performance of the Goldberg Anxiety and Depression Scale in older women. Age and ageing, 37(4), 464-467. doi:10.1093/ageing/ afn091 https://doi.org/10.1093/ageing/afn091

Lloret-Segura, S., Ferreres-Traver, A., HernándezBaeza, A., \& Tomás-Marco, I. (2014). El análisis factorial exploratorio de los ítems: una guía práctica, revisada y actualizada. Anales de psicología, 30(3), 1151-1169. doi:10.6018/ analesps.30.3.199361

López, M., Gabarrón, R., \& Ruiz, A. (febrero-marzo de 2011). Depresión en atención primaria: una aproximación a los trabajos realizados en España. Trabajo presentado en el XII Congreso Virtual de Psiquiatría Interpsiquis 2011.

Lorenzo-Seva, U. (1999). Promin: A method for oblique factor rotation. Multivariate Behavioral Research, 34(3), 347-365. doi:10.1207/ S15327906MBR3403_3

Mackinnon, A., Christensen, H., Jorm, A., Henderson, A., Scott, R., \& Korten, A. (1994). A latent trait analysis of an inventory designed to detect symptoms of anxiety and depression using an elderly community sample. Psychological Medicine, 24(4), 977-986. doi:10.1017/ S0033291700029068

Magnavita, N. (2007). Anxiety and depression at work. The A/D Goldberg Questionnaire. Giornale Italiano di Medicina del Lavoro ed Ergonomia, 29(3 Suppl), 670-671. Recovered from https:// europepmc.org/abstract/med/18409897

Malhotra, K.N., \& Dash, S. (2011), Marketing Research: An Applied Orientation (6th ed.). India: Dorling Kindersley Inda, Noida and Pearson Education.
Martín Carbonell, M., Pérez Díaz, R., \& Riquelme Marín, A. (2016). Valor diagnóstico de la Escala de Ansiedad y Depresión de Goldberg (EAD-G) en adultos cubanos. Universitas Psychologica, 15(1), 177-192. doi:10.11144/Javeriana.upsy15-1. vdea

Montón, C., Pérez Echeverría, M. J., Campos, R., García Campayo, J., \& Lobo, A. (1993). Escalas de ansiedad y depresión de Goldberg: una guía de entrevista eficaz para la detección del malestar psíquico. Aten Primaria, 12(6): 345349. Recovered from http://pesquisa.bvs.br/ aps/resource/es/mdl-8218816

Muthén, B., \& Hofacker, C. (1988). Testing the assumptions underlying tetrachoric correlations. Psychometrika, 53(4), 563-578. doi:10.1007/ BF02294408

Nunnally, J. C. (1975) The study of change in evaluation research: principles conconcerning measurement, experimental design and analysis. In E. L. Streuning \& M. Guttentag (eds.) Handbook of Evauation Research (pp. 101-138). Beverly Hills, CA: Sage

Nunnally, J. C., \& Bernstein, I. H. (1994). Psychometric Theory (3rd. ed.). New York: McGraw-Hill

Pérez Gil, J. A., Chacón Moscoso, S., \& Moreno Rodríguez, R. (2000). Validez de constructo: el uso de análisis factorial exploratorio-confirmatorio para obtener evidencias de validez. Psicothema, 12 (Supl. 2), 442-446. Recovered from http:// www.psicothema.es/pdf/601.pdf

Price, J. H., \& Murnan, J. (2004). Research Limitations and the Necessity of Reporting Them. American Journal of Health Education, 35(2), 66-67. doi:1 0.1080/19325037.2004.10603611

Salvador, L., Romero, C. \& González, F. (2000). Guías para la descripción y la selección de instrumentos de evaluación en psiquiatría. En: A. Bulbena, G.E. Berrios, \& P.F. De Larrinoa (Eds.), Medición clínica en psiquiatría y psicología (pp. 15-33). Barcelona: Masson.

Timmerman, M. E., \& Lorenzo-Seva, U. (2011). Dimensionality assessment of ordered polytomous items with parallel analysis. Psychological Methods, 16(2), 209-220. doi:10.1037/ a0023353

Varo, M. B., Fernández, M. O., Cobos, F. M., Gutiérrez, P. V., \& Aragón, R. B. (2006). Intervención grupal en los trastornos de ansiedad en Atención Primaria: técnicas de relajación y cognitivo-conductuales. SEMERGEN-Medicina de Familia, 32(5), 205-210. doi:10.1016/ S1138-3593(06)73258-0 
Vergara-Romero, M., Morales-Asencio, J. M., MoralesFernández, A., Canca-Sanchez, J. C., Rivas-Ruiz, F., \& Reinaldo-Lapuerta, J. A. (2017). Validation of the Spanish version of the Amsterdam Preoperative Anxiety and Information Scale (APAIS). Health and quality of life outcomes, 15(1), 120. doi:10.1186/s12955-017-0695-8

Werts, C. E., Linn, R. L., \& Jöreskog, K. G. (1974). Intraclass Reliability Estimates: Testing Structural Assumptions. Educational and Psychological Measurement, 34(1), 25-33. doi:10.1177/001316447403400104

World Health Organization (1992), CIE-10. Décima revisión de la clasificación internacional de las enfermedades. Trastornos mentales y del comportamiento. Descripción clínica y pautas para el diagnóstico, Madrid. Ed. Méditor.

World Health Organization, WHO (2003). Informe sobre la salud en el Mundo 2003: forjemos el futuro. Ginebra, Organización Mundial de la Salud. Recovered from: https://www.who.int/ whr/2003/es/ 